\title{
First record of Corbicula largillierti (Philippi 1844) in the Paraíba River Basin and potential implications from water diversion of the São Francisco River
}

\author{
Evaldo de Lira Azevêdo ${ }^{1,3}$, José Etham de Lucena Barbosa, Teofânia H. D. A. Vidigal ${ }^{2}$, Marcos Callisto ${ }^{2}$ \& \\ Joseline Molozzi ${ }^{1}$ \\ ${ }^{1}$ Departamento de Biologia, Programa de Pós-graduação em Ecologia e Conservação, Universidade \\ Estadual da Paraíba, Campina Grande, PB, Brazil. \\ ${ }^{2}$ Universidade Federal de Minas Gerais, Belo Horizonte, MG, Brazil. \\ ${ }^{3}$ Corresponding author: Evaldo de Lira Azevêdo, e-mail: evaldoazevedo@yahoo.com.br
}

\begin{abstract}
AZEVÊDO, E.L., BARBOSA, J.E.L, VIDIGAL, T.H.D.A, CALLISTO, M., MOLOZZI, J. First record of Corbicula largillierti (Philippi 1844) in the Paraíba River Basin and potential implications from water diversion of the São Francisco River. Biota Neotropica. 14(4): e20140036. http://dx.doi.org/10.1590/1676-0603003614
\end{abstract}

\begin{abstract}
Corbicula largillierti is a native mollusk from China. In Brazil, this species was first recorded in the Pantanal of Mato Grosso. This short communication reports the occurrence of $C$. largillierti for the first time in the Paraíba river basin (Brazilian semi-arid), and also considers the risk of introduction of other molluscs invaders in this basin due to the diversion of water from the São Francisco River. Densities of individuals ranged from 33 to 65 ind. $\mathrm{m}^{-2}$ (maximum values of 484 ind. $\mathrm{m}^{-2}$ ) in coarse sediment (gravel, 2-4 mm). The diversion of waters from the São Francisco river can lead to the introduction of new species, enhancing ecological problems in the Paraiba river basin.
\end{abstract}

Keywords: Invasive species, Semi-arid, Molluscs, Corbiculidae.

\begin{abstract}
AZEVÊDO, E.L., BARBOSA, J.E.L, VIDIGAL, T.H.D.A, CALliSTO, M., MOLOZZI, J. Primeiro registro de Corbicula largillierti (Philippi 1844) na bacia do Rio Paraíba e implicações potenciais com a transposição das águas do Rio São Francisco. Biota Neotropica. 14(4): e20140036. http://dx.doi.org/10.1590/ 1676-0603003614
\end{abstract}

\begin{abstract}
Resumo: Corbicula largillierti é um molusco nativo da China. No Brasil esta espécie foi registrada primeiramente no Pantanal do Mato Grosso. Esta nota registra a primeira ocorrência de C. largillierti na bacia do Rio Paraíba (semiárido brasileiro). Considera também os riscos potenciais de introdução de outros moluscos invasores nesta bacia devido à transposição das águas do Rio São Francisco. As densidades do molusco variaram de 33 a 65 ind. $\mathrm{m}^{-2}$ (atingindo valor máximo de 484 ind. $\mathrm{m}^{-2}$ ) em sedimentos grossos (cascalho, 2-4 mm). A transposição das águas do Rio São Francisco pode ocasionar a introdução de novas espécies exóticas potencializando problemas ecológicos na bacia do Rio Paraíba.
\end{abstract}

Palavras-chave: Espécies invasoras, Semiárido, Moluscos, Corbiculidae.

\section{Introduction}

The introduction of exotic species is the second most important cause for biodiversity loss in global scale (Darrigran et al. 2011). Exotic species can become pests (Fernandes et al. 2012) and cause a range of problems with environmental and human health consequences, as well as, economical and even political implications (Shine 2007). Therefore, the study of the dynamics and distribution of invasive species can explain the process of invasion and predict the dispersion patterns of these species (Darrigran et al. 2009).

Corbicula largillierti is a freshwater bivalve belonging to the Corbiculidae family (Bivalvia, Heterodonta, Veneroida) from Asian origin and endemic of lakes from the Yangtze Kiang river systems, in China. In has been found in several areas in South America (Mansur et al. 2004) but for the first time in the Rio de la Plata River, near Buenos Aires (Ituarte 1981). It has latter been recorded in Uruguay (Ituarte 1984) and again in Argentina (Ituarte 1994). In Brazil, Corbicula largillierti was first recorded in the Pantanal, Mato Grosso (Callil \& Mansur 2002) and latter in the Sinos River basin, Rio Grande do Sul (Mansur \& Pereira 2006). Recently, the species was recorded in Minas Gerais, Espírito Santo, Santa Catarina and Ceará states (Silva \& Barros 2011). In a recent review, Pereira et al. (2012) reported $C$. largillierti for the Brazilian northeastern coastal basins, the São Francisco River, eastern, southern and southeastern basins, as well as the Paraná/Paraguay and Uruguay basins.

The waters from the São Francisco river will be diverted to the Paraiba river basin (Brasil 2007). This divertion is likely to cause ecological damage to the receiving basins with the introduction of exotic species, water pollution and decrease in discharges of the São Francisco river (Li et al. 2013) as well as proliferation of green algae (Zhu \& Ketola 2012). 


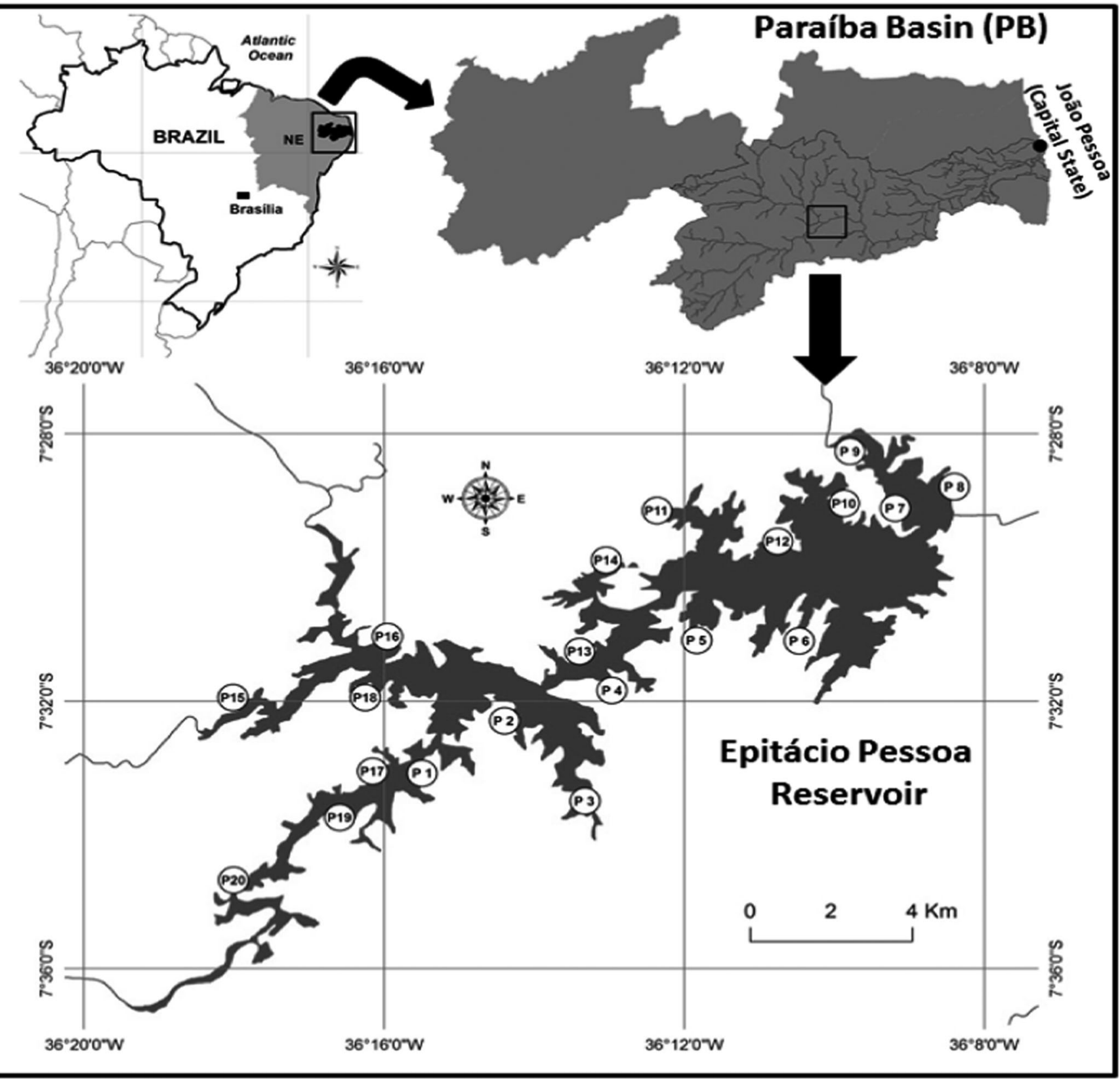

Figure 1. Sampling sites reservoir Epitácio Pessoa, Paraíba River basin, Brazilian semiarid.

This short communication reports the occurrence of $C$. largillierti for the first time in the Paraíba basin river (Brazilian semi-arid) and also considers the risk of the introduction of other mollusc invaders in this basin due to the diversion of waters from the São Francisco River.

\section{Materials and Methods}

\section{Study Area}

The Paraíba river basin (Figure 1) encompasses an area of $20,071.83 \mathrm{~km}^{2}$ (6 $\left.6^{\circ} 51^{\prime} 31^{\prime \prime}-8^{\circ} 26^{\prime} 21^{\prime \prime} \mathrm{S} ; 34^{\circ} 48^{\prime} 35^{\prime \prime}-37^{\circ} 2^{\prime} 15^{\prime \prime} \mathrm{W}\right)$. This basin is the second largest of the Paraíba State, covering $38 \%$ of the State and harboring $1,828,178$ inhabitants $(52 \%$ of the State population). This basin is, therefore, among the most important freshwater systems in the Brazilian semi-arid
(Paraíba, 2012) being also a receiver of waters to be diverted from the São Francisco river.

\section{Sampling}

The specimens of $C$. lagillierti from the present study were collected in sediment samples from 20 sites taken from the margins of the Epitácio Pessoa reservoir ( $7^{\circ} 28^{\prime} 4^{\prime \prime}-7^{\circ} 33^{\prime} 32^{\prime \prime}$ $\left.\mathrm{S}, 36^{\circ} 8^{\prime} 23^{\prime \prime}-36^{\circ} 16^{\prime} 51^{\prime \prime} \mathrm{W}\right)$ located in the Paraíba river, Brazilian semiarid region. Samples were taken using a VanVeen $\left(477 \mathrm{~cm}^{2}\right)$ dredge in June 2010 and December 2011.

\section{Results and Discussion}

Corbicula largillierti is easily mistaken for the C. fluminea, the former having a fragile shell, lower height and lower umbos (Mansur \& Pereira 2006, Pereira et al. 2012). The 


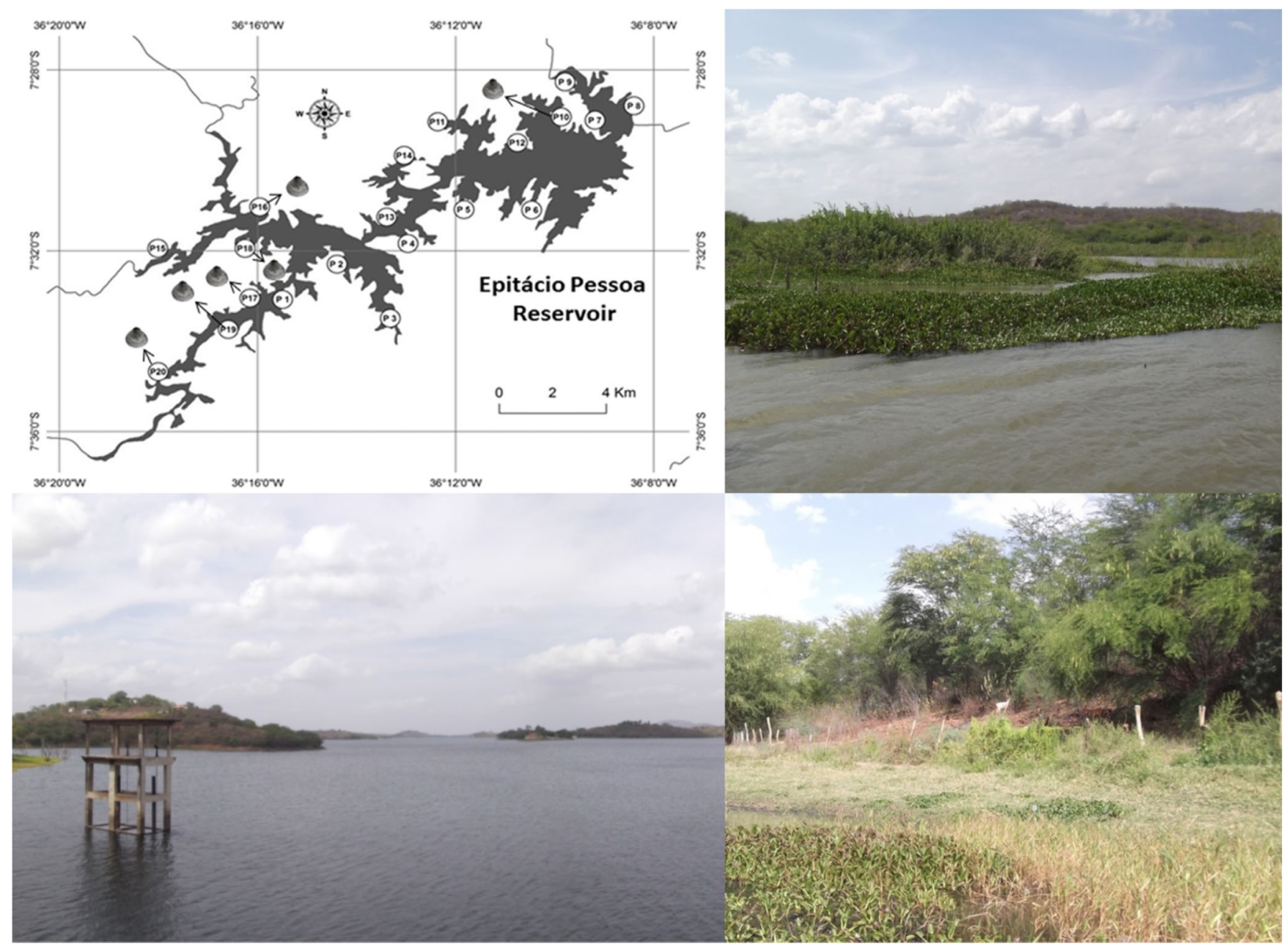

Figure 2. Reservoir Epitácio Pessoa and places of occurrence Corbicula largillierti, Paraíba River basin, Brazil.

introduction of Corbiculidae in freshwater ecosystems may alter fish diets and impair industrial activities, leading to economical loss (Darrigran 2002, Santos et al. 2012). It can also cause damage to human health given that some Corbiculidae are bioaccumulators of heavy metals (Darrigran 2002, Santos et al. 2012).

Densities of individuals ranged from 33 to 65 ind. $\mathrm{m}^{-2}$ (maximum values of 484 ind. $\mathrm{m}^{-2}$ ) in coarse sediments (gravel, 2$4 \mathrm{~mm}$ ), in six sampling sites (Figure 2). Identification of specimens was performed through shell characterization according to Mansur et al. (2004) and Pereira et al. (2012). The specimens were deposited in the Reference Collection of the Malacology and Molecular Systematics Laboratory of Universidade Federal de Minas Gerais, lots LMSM 3582 and 3583 (Figure 3).

The introduction of the mollusk in the study reservoir may have happened due to a variety of reasons. Given the higher densities near entry points of tributary streams into the reservoir, we believe that the mollusk was carried into the reservoir from these affluent tributaries. An alternative is that Corbicula largillierti may have been brought along with exotic molluscivorous fish that have been introduced into the reservoir (Gurgel \& Fernando 1994). It is known that some species of

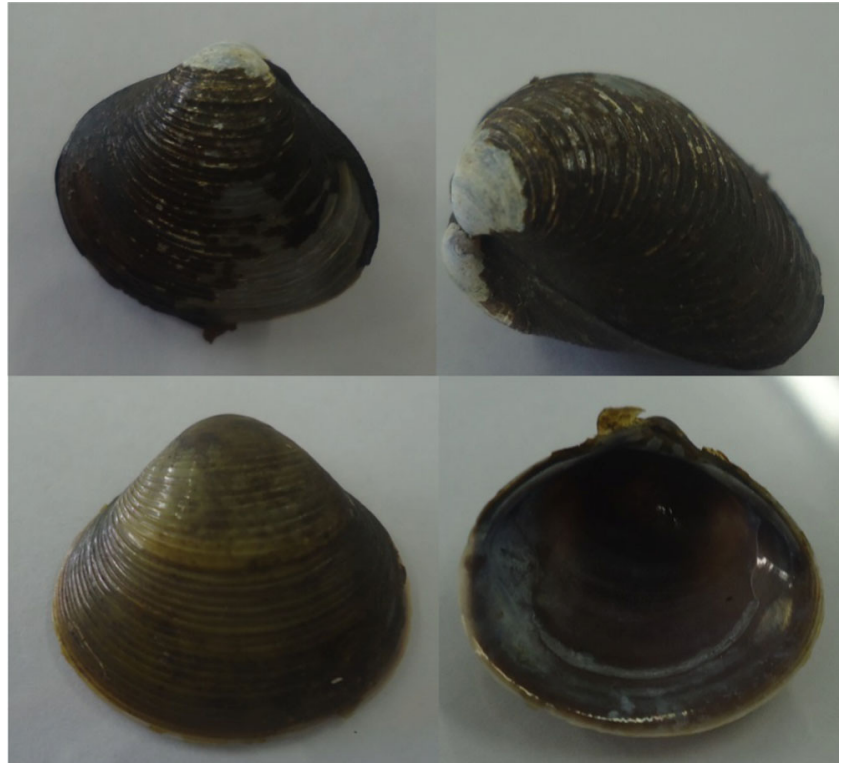

Figure 3. Record of Corbicula largillierti, reservoir Epitácio Pessoa, Paraíba River basin, Brazil. 
mollusks can stay alive even after passing through the digestive tract of fish. Another possible way for the introduction of Corbicula largillierti is through the many small boats which are commonly used in the reservoir for fishing, recreation and inspection (Fernandes et al. 2012).

The presence of $C$. largillierti and other introduced species, such as Melanoides tuberculatus (Müller 1774) (Caenogastropoda, Thiaridae) (Paz et al. 1995), in the Paraíba river basin are examples of the threat of dispersion of exotic species throughout aquatic systems, which is commonly magnified by river flow and aquatic birds (Figuerola \& Green 2002). Furthermore, in a study on niche models, Oliveira et al. (2010) highlighted the potential threat of the introduction of Limnoperna fortunei (Dunker 1857) (Bivalvia, Mytilidae) in the São Francisco river basin. With the water diversion from this basin, this species may spread to the Paraiba river basin, affecting native species of fish and mollusks. Another invasive mussel, which has caused serious environmental damage, Corbicula flumminea (Muller 1774), has also invaded semiarid ecosystems. There is the risk that shellfish reach the Paraíba River basin as a result of the diversion of waters from the São Francisco River, considering that this has already been recorded in the Hydroelectric of Xingó, in the São Francisco River Basin (state of Sergipe) (Santana et al. 2013).

Water diversions have been reported to alter water flow. In the Paraiba river, which is an intermittent system, it is expected that the water flow become perennial, which will lead to modifications of the habitat characteristics and will favor invasive species (Kingsford 2000). Changes in flow regime have been associated with the invasion success of introduced species. Hence, the water diversion of the São Francisco river invasive species may become established given that (i) the natural water flow is a major player in habitat structure; (ii) aquatic species have specific strategies to respond to flow regime; and (iii) the maintenance of natural patterns of longitudinal and lateral connection are essential to the viability of riverine species (Bunn \& Arthington, 2002).

The semi-arid region of Brazil has been receiving alien species for many years. Government policies executed by the Departamento Nacional de Obras Contra a Seca (DNOCS) led to the introduction of 42 species of fish and crustaceans in over 100 reservoirs in the semi-arid region (Gurgel \& Fernando 1994). This is a threat to native diversity and highlights the need for more studies on the introduction of species in the semi-arid region, especially as a consequence of the São Francisco river waters diversion.

We propose that future studies on the subject should use a niche modeling approach (e.g.: Peterson and Vieglais 2001) and evaluate limiting abiotic factors in order to predict systems at risk of species invasion (Darrigran et al. 2011).

\section{Acknowledgments}

We thank Coordenação Aperfeiçoamento de Pessoal de Nível Superior (Capes) for the provision of a masters scholarship that enabled the development of this work, the Universidade Estadual da Paraíba (UEPB), all of Laboratório de Ecologia de Bentos and Laboratório de Ecologia Aquática (UEPB), Universidade Federal de Minas Gerais. MC was awarded a research productivity grant by the $\mathrm{CNPq}$ - Conselho Nacional de Desenvolvimento Científico e Tecnológico (CNPq No. 302960/2011-2) and a Minas Gerais researcher grant by FAPEMIG - Fundação do Amparo à Pesquisa do Estado de Minas Gerais (FAPEMIG PPM-00077/13).

\section{References}

CALLIL, C.T. \& MANSUR, M.C.D. 2002. Corbiculidae in the Pantanal: history of invasion in souther and South America and biometrical data. Amazoniana 17(1):153-167.

BUNN, S.E. \& ARTHINGTON, A.H. 2002. Basic principles and ecological consequences of altered flow regimes for aquatic biodiversity. Environmental management 30(4):492-507, http:// dx.doi.org/10.1007/s00267-002-2737-0

DARRIGRAN, G. 2002. Potential impact of filter-feeding invaders on temperate inland freshwater environments. Biological Invasions 4(1):145-156, http://dx.doi.org/10.1023/A:1020521811416

DARRIGRAN, G., BOEGER W., BAMBORENEA, C. \& MAROÑAS, M. 2009. Evaluation of sampling and analysis techniques for early detection of Limnoperna fortunei (Mytilidae) in limit areas of its distribution. Braz. J. Biol. 69(3):979-980, http:// dx.doi.org/10.1590/S1519-69842009000400029

FERNANDES, F.C., MANSUR, M.C.D., PEREIRA, D., FERNANDES, L.U.G., CAMPOS, S.C. \& DANELOS, O.M. 2012. Abordagem conceitual dos moluscos invasores nos ecossistemas límnicos brasileiros. In: MANSUR, M.C.D, SANTOS, C.P., PEREIRA, D., PAZ, I.C.P., ZURITA, M.L.L., RODRIGUEZ, M.T.R., NEHRKE, M.V. \& BERGONCI, P.E.A. Moluscos límnicos invasores no Brasil: biologia, prevenção e controle. Porto Alegre: Redesp. 19-23.

FIGUEROLA, J. \& GREEN, A.J. 2002. Dispersal of aquatic organisms by waterbirds: a review of past research and priorities for future studies. Freshwater Biology 47(1):482-494.

GURGEL, J.J.S. \& FERNANDO, C.H. 1994. Fishes in semi-arid northeast Brazil with special reference to the role of tilapias. Internationale Revue der gesamten Hydrobiologie und Hydrographie 79(1):77-94.

ITUARTE, C.F. 1984. Aspectos biológicos de las poblaciones de Corbicula largillierti (Philippi, 1844) (Mollusca, Pelecypoda) en el Rio de La Plata. Revista del Museu de La Plata 13(143):231-247. 